\title{
Elemental contamination of an open-pit mining area in the Peruvian Andes
}

\author{
F. Bianchini - G. Pascali • A. Campo • \\ S. Orecchio $\cdot$ R. Bonsignore $\cdot$ P. Blandino $\cdot$ \\ P. Pietrini
}

Received: 21 December 2012/Revised: 18 December 2013/Accepted: 21 December 2013/Published online: 21 January 2014

(C) Islamic Azad University (IAU) 2014

\begin{abstract}
New technologies and higher prices of raw materials have promoted the expansion of mining activity throughout the world; if not properly regulated, this activity can lead to contamination of the local and regional environment. The city of Cerro de Pasco is located close to a large open-pit mine and in recent years, several reports have provided evidence of environmental contamination and related health problems. The aim of this paper is to evaluate the contamination in fluvial water, sediments and biological fluids from this area. The collective results show elevated metal and metalloid concentrations in rivers and sediments, especially in the areas downstream of the mine. For instance, $\mathrm{Pb}$ concentration in rivers downstream of the mine was $4.451 \mathrm{mg} / \mathrm{L}$, while it was $0.037 \mathrm{mg} / \mathrm{L}$ upstream of the mine. Sediments also
\end{abstract}

F. Bianchini $(\square)$

Source International, Via Ruschi 72, 56011 Calci, PI, Italy

e-mail: flaviano@source-international.org

F. Bianchini

Department of Natural Science, University of Pisa, Pisa, Italy

G. Pascali

Lifesciences, ANSTO, Sydney, Australia

G. Pascali · A. Campo · P. Pietrini

Laboratory of Specialized Biochemical Analysis, Medicine

Faculty, University of Pisa, Pisa, Italy

S. Orecchio $\cdot$ R. Bonsignore $\cdot$ P. Blandino

STEBICEF, University of Palermo, Palermo, Italy

P. Pietrini

Director, Laboratory of Clinical Biochemistry and Molecular Biology, University of Pisa, Pisa, Italy

P. Pietrini

Director, Clinical Psychology Branch, Pisa University Hospital, Pisa, Italy show higher concentration of metals and metalloids in the areas under the influence of the mine. Concentrations of elements in human blood were measured in the population of Paragsha, a village close to the mine. Analysis of the blood samples revealed elevated levels of metals and metalloids, particularly $\mathrm{Pb}, \mathrm{Cr}, \mathrm{Al}, \mathrm{Ni}$ and $\mathrm{Mn}$. All of the studied population showed blood concentrations of $\mathrm{Al}, \mathrm{Cr}$ and $\mathrm{Ni}$ higher than those recommended by the WHO. The high concentration of elements found in the blood of the population could be related to the high concentration in the surrounding water sources, but further studies are required to determine the exact sources of exposure to these metals and metalloids.

Keywords Bioaccumulation - Heavy metals · Open-pit mine $\cdot$ Water contamination

\section{Introduction}

During the twentieth century, the central Andes of Peru experienced rapid industrialization, primarily through mining. This development has led to an increase in heavy metal emissions and their subsequent deposition in seemingly pristine mountain environments (Cooke and Abbott 2008). The deposition of heavy metals from the mining centers has had a negative impact on the surrounding water quality, as well as a potential impact on the health of the local inhabitants (e.g., bioaccumulation of heavy metals in human tissues).

Mining-related contamination has been reported in several areas all around the world. Some studies have compared the metal contamination of soil in mined areas with soil in non-mine areas (Ngole and Ekosse 2012). Contamination related to open-pit mining activity can easily pass from soil to plants, entering the food chain and thus affecting humans (Ashraf et al. 2011). 
Many studies (most of them from the Ministry of Health of Peru) report contamination of waters in the area (Reporte anual de salud ambiental 2007; Reporte anual de salud ambiental 2009). Other studies (Conklin et al. 2008) have shown increased concentrations of metals and metalloids in the blood of the inhabitants of the city of Cerro de Pasco. The latter report also showed that $53 \%$ of children and $9 \%$ of fertile women had more than $10 \mu \mathrm{g} / \mathrm{dL}$ of $\mathrm{Pb}$ in blood, while $63 \%$ of children and $70 \%$ of fertile women had concentrations of Cs above the recommended limit. In addition, the reported noted that $71 \%$ of both children and fertile women had dangerously high levels of $\mathrm{Tl}$.
A possible consequence of this reported contamination might be related to the data published by the Ministry of Health in 2007, showing that in Cerro de Pasco, $15.8 \%$ of infant mortality was due to "congenital malformations."

The objective of this paper is therefore to further evaluate the water quality in the mining area of Cerro de Pasco and assess the bioaccumulation of several metals and metalloids in the blood of the inhabitants of the city by using atomic absorption.

The city of Cerro de Pasco is the capital of the Pasco region and is located on the high plateau of central Peru as shown in Fig. 1. The area has been known to contain silver
Fig. 1 Map of Peru, in the red square the area of the study

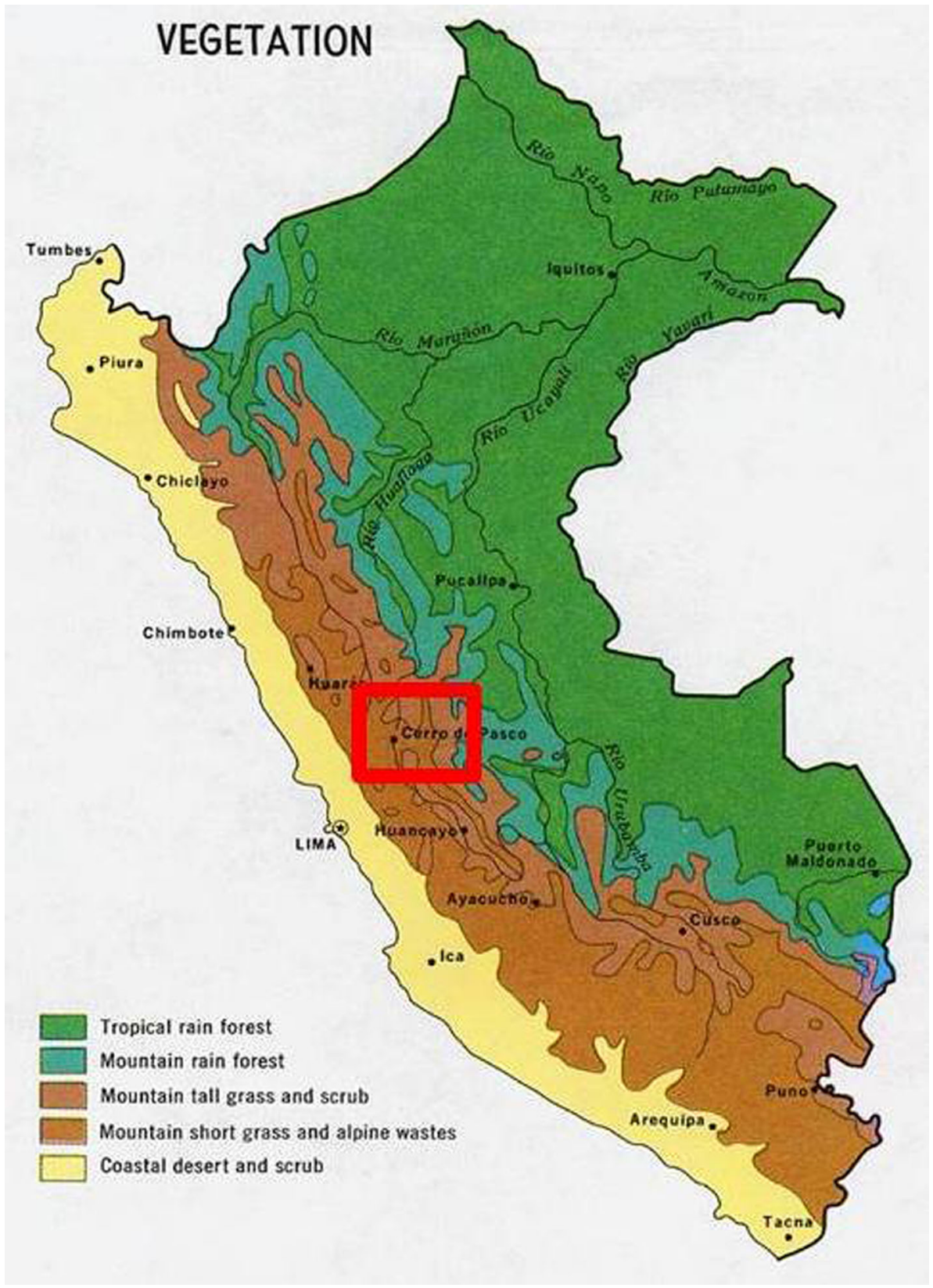


since the pre-Columbian era. Ancient chronicles report that part of the silver used for the Atahualpa ransom has come from the Cerro de Pasco mines. In fact, the region became one of the most important producers of silver in the world with the onset of Spanish mining activities in 1630 (Fisher 1977).

The primary mineral mined at Cerro de Pasco has been enargite $\left(\mathrm{Cu}_{3} \mathrm{AsS}_{4}\right)$, but main ores also contain combinations of aramayoite $\left[\mathrm{Ag}(\mathrm{Sb}, \mathrm{Bi}) \mathrm{S}_{2}\right]$, arsenopyrite (FeAsS), argentiferous galena $[(\mathrm{Ag}, \mathrm{Pb}) \mathrm{S}]$, chalcopyrite $\left(\mathrm{CuFeS}_{2}\right)$, tennantite $\left(\mathrm{Cu}_{12} \mathrm{As}_{4} \mathrm{~S}_{13}\right)$, sphalerite $[(\mathrm{Zn}, \mathrm{Fe}) \mathrm{S}]$ and grantonite $\left(\mathrm{Pb}_{9} \mathrm{As}_{4} \mathrm{~S}_{15}\right)$ (Einaudi 1977; Purser 1971; Ward 1961).

The open-pit mine of Cerro de Pasco has been exploited mostly for copper production, though gold, lead, bismuth and zinc were also mined (Benavides 1990). It is estimated that before the start of Spanish mining activities, the area contained one thousand tons of silver, four million tons of zinc, two million tons of lead and smaller amounts of gold and bismuth (Einaudi 1977; Peterson 1965). The extraction of copper and bismuth has been discontinued, and the mine is mostly used for the mining of zinc, lead, silver and gold. The mine is the largest open-pit mine in Peru for zinc.

Cerro de Pasco contains 80,000 inhabitants and encircles the opening of the mine; there is very short distance between the city buildings and the mining zone, and some houses are as close as five meters from the edge of the pit. The water used for the extraction process is routed directly into the local rivers, while the solid mining waste has accumulated in waste dumps throughout the city. Therefore, the possible impact on the health of the resident population resulting from such mine activity is of interest as it relates to the metal and metalloid accumulation in human tissues.

The population analyzed for these studies does not have work-related elemental exposure and comprised 24 children, between 6 and 12 years old, and 17 adults. The research was carried out in the city of Cerro de Pasco during January-March 2009.

\section{Materials and methods}

Analysis of inorganic samples

\section{Materials}

Nitric acid used for mineralization was Suprapur (Merck). All other reagents used for analysis were of analytical reagent grade (Merck). Solutions of $\mathrm{Cd}, \mathrm{Cr}, \mathrm{Cu}, \mathrm{Ni}, \mathrm{Pb}$ and $\mathrm{Zn}$ (100 mg/L) (Merck) were used to prepare the calibration standard solutions.

\section{Instrumentation}

Weight losses were obtained by ignition using an electric muffle furnace. Mineralization was achieved using a highperformance microwave digestion unit, Milestone model MLS 1200 Mega. This was equipped with high-pressure digestion bombs consisting of a body made of a specific microwave-transparent polymer with a Teflon cup and cover. A PerkinElmer (model Analyst 3000) atomic absorption spectrometer equipped with flame was then used to estimate the concentration of each metal and metalloid investigated.

\section{Sample collection and storage}

The water samples were collected in sterile, dark plastic bottles. These containers were washed copiously with the sample water prior to collection. The collected samples were acidified with $2 \mathrm{~mL}$ of nitric acid and stored in a refrigerated area until the analysis.

Sediment samples were collected in the riverbed directly with a clean bucket. About $25 \mathrm{~L}$ of sediments was collected directly from the riverbed. After collection and "in loco" successive quartering, the samples were stored in a $500-\mathrm{mL}$ polyethylene container at $4{ }^{\circ} \mathrm{C}$ and shipped.

\section{Water content analysis}

About $2 \mathrm{~g}$ of homogenized sample was dried at $105^{\circ} \mathrm{C}$ for $12 \mathrm{~h}$. The water content was determined by weight loss and was used to establish the concentration on a dry weight basis.

\section{Organic matter}

Total organic matter of the sediments was determined by ignition at $550{ }^{\circ} \mathrm{C}$ for $6 \mathrm{~h}$. The organic content was determined by weight loss.

\section{Sequential extraction procedure of metals and metalloids} from sediments

One of the major drawbacks of sequential extraction procedures is the time required for extraction (4-5 days). To reduce the extraction time, step 4 of Tessier's original procedure (Tessier et al. 1979) was substituted by mineralization in a microwave oven with $6 \mathrm{~mL}$ of concentrated $\mathrm{HNO}_{3}$. The digestion conditions of mineralization are reported in Table 1.

The accuracy and reliability of this procedure has been established previously (Culotta et al. 2008).

Particular attention was paid to determining the reaction times of each extraction step. The optimized extraction procedure is reported as follows: 
Table 1 Conditions of mineralization

\begin{tabular}{ll}
\hline Time $(\min )$ & Power $(\mathrm{W})$ \\
\hline $6: 00$ & 250 \\
$6: 00$ & 400 \\
$6: 00$ & 500 \\
$6: 00$ & 250 \\
\hline
\end{tabular}

Fraction 1 (exchangeable metals and metalloids) Sediment sample ( $2.5 \mathrm{~g}$ dry weight) was treated with $10 \mathrm{~mL}$ of $1 \mathrm{M}$ sodium acetate solution for $1 \mathrm{~h}$ under continuous stirring. A residue was obtained by centrifugation at $5,000 \mathrm{rpm}$. The residue was washed twice with the extraction solution, and the obtained solution was added to the previous one. Before starting the following steps, the residue was washed with water.

Fraction 2 (metals and metalloids bound to carbonates) The residue obtained from step 1 was stirred with $20 \mathrm{~mL}$ of $1 \mathrm{M} \mathrm{CH}_{3} \mathrm{COONH}_{4}$ solution at $\mathrm{pH} 5$ (adjusted with acetic acid) for $24 \mathrm{~h}$. A new residue was obtained by centrifugation at 5,000 rpm. The residue was washed twice with the extraction solution and the obtained solution was added to the previous one. Then, the residue was washed with water.

Fraction 3 (metals and metalloids bound to $\mathrm{Fe}$ and $\mathrm{Mn}$ oxides) The residue from step 2 was treated with $1 \mathrm{M}$ $\mathrm{NH}_{2} \mathrm{OH} \cdot \mathrm{HCl}$ solution in $25 \% \mathrm{CH}_{3} \mathrm{COOH}(1: 1 \mathrm{v} / \mathrm{v})$ under stirring at $96{ }^{\circ} \mathrm{C}$, until the free iron-manganese oxides were completely dissolved. The reaction time was approximately $24 \mathrm{~h}$. The residue was treated as in the previous step.

Fraction 4 (metals and metalloids bound to organic matter and/or to sulfide) The organic fraction of the residue from step 3 was mineralized in a high-performance microwave digestion unit by means of $6 \mathrm{~mL} \mathrm{HNO}_{3}$. A new residue was obtained after centrifugation and solution removal.

\section{Determination of heavy metals from fractions}

Metal and metalloid analyses of each extracted fraction were carried out by graphite furnace atomic absorption spectrometry (GFAAS). For this purpose, quantification of heavy metals was achieved using external standard solutions.

Analysis of biological fluids

\section{Materials}

All aqueous metal standard solutions $(1,000 \mu \mathrm{g} / \mathrm{mL})$ were supplied either from Aldrich or from SpectroPure. Certified reference materials (CRM) of serum, blood and urine were obtained from Seronorm. The standard solutions used for the analyses were prepared by dilution in volumetric flasks and stored in $60-\mathrm{mL}$ Nalgene bottles. The standard solutions were stable for up to 1 month after preparation, as verified by the accuracy in the determination of analytical values in CRM samples. The Nalgene bottles were stored at $4{ }^{\circ} \mathrm{C}$. Triton X-100 was purchased from Aldrich; distilled water was produced by a Millipore Direct- $\mathrm{Q}_{3}$ purification apparatus.

\section{Instrumentation}

Analyses were performed on a Varian AA240Z atomic absorption spectrometer. Solutions were prepared using air displacement pipettors with plastic disposable tips either in polystyrene clean tubes or directly into the polystyrene sample cups used in the autosampler.

\section{Sample collection and storage}

Serum Serum samples were collected using Vacutest tubes (Beckton Dickinson) not containing clot activators. Sera were partitioned by centrifugation at 3,500 rpm for $5 \mathrm{~min}$ and then separated and stored in clean polyethylene tubes at $-20^{\circ} \mathrm{C}$. Samples for $\mathrm{Al}$ analysis were drawn from the venous stream directly with a polyethylene syringe (since the rubber septa of the Vacutest tubes occasionally released $\mathrm{Al}$ ); about $8 \mathrm{~mL}$ of this blood was placed in a standard urine $10-\mathrm{mL}$ polyethylene tube and centrifuged. For the other elements, the collected sera for $\mathrm{Al}$ were stored at $-20{ }^{\circ} \mathrm{C}$.

Whole Blood Whole-blood samples were drawn from the venous stream using Vacutest tubes (Beckton Dickinson) containing Li-heparin as anticoagulant. The tubes were stored at $4{ }^{\circ} \mathrm{C}$ without centrifugation and gently shaken for homogenization before the sample preparation.

\section{Analysis of elements}

Predilution and standards Table 2 reports a scheme of preparation for each analysis.

Injection and calibration The injection was checked for repeatability with a digital camera aimed into the graphite tube. Whenever the drop was not properly deposited (or not at all) or not properly dried, care was taken in the evaluation of the final analytical result by deleting out-of-range points, aligning the pipettor or replacing the atomization tube. Prediluted samples were used, rather than undiluted ones, because the dense organic matrices of the latter resulted in complicated aspiration by the autosampler pipettor. 
Table 2 Typical dilution and standard additions

Table 3 Heating programs for the furnace

a Preinjection of Pd solution in first steps of drying

b Slow cooling

\begin{tabular}{lllll}
\hline Element & Matrix & Typical sample predilution & Std solution $(\mu \mathrm{g} / \mathrm{L})$ & Std additions $(\mu \mathrm{g} / \mathrm{L})$ \\
\hline $\mathrm{Al}$ & Serum & $1 / 2$ with $0.5 \%$ Triton X-100 & 50 & $5,10,20$ \\
$\mathrm{As}^{\mathrm{a}}$ & Blood & $1 / 2$ with $0.5 \%$ Triton X-100 & 250 & $25,50,100$ \\
$\mathrm{Cd}^{\mathrm{a}}$ & Blood $^{\mathrm{b}}$ & $1 / 5$ with $0.5 \%$ Triton X-100 & $10^{\mathrm{b}}$ & $1,2,4$ \\
$\mathrm{Cr}$ & Serum & $1 / 2$ with $\mathrm{H}_{2} \mathrm{O}$ & 5 & $0.5,1.0,2.0$ \\
$\mathrm{Cu}$ & Serum & $1 / 21$ with $0.5 \%$ Triton X-100 & 250 & $25,50,75$ \\
$\mathrm{Mn}$ & Blood & $1 / 6$ with $0.5 \%$ Triton X-100 & 10 & $1,2,4$ \\
$\mathrm{Ni}^{\mathrm{a}}$ & Serum & $1 / 2$ with $\mathrm{H}_{2} \mathrm{O}$ & 20 & $2,4,8$ \\
$\mathrm{~Pb}^{\mathrm{a}}$ & Blood & $1 / 11$ with $0.5 \%$ Triton X-100 & 100 & $10,20,30$ \\
$\mathrm{Se}^{\mathrm{a}}$ & Serum & $1 / 2$ with $0.5 \%$ Triton X-100 & 250 & $25,50,75$ \\
\hline
\end{tabular}

Thermal temperature programs The most delicate aspect of optimizing GFAAS methods was the determination of a proper temperature scale that would allow smooth drying of the sample, complete ashing, high-yielding final atomization and quick cleaning and reconditioning. At this stage, it was important to evaluate the usefulness of a modifier for matrix digestion or for metal fixation on the tube. The heating programs used in our methods are reported in Table 3.

Method validation The methods used for analyzing blood samples have been tested and validated using CRM. The statistical features of the procedures are summarized in Table 4.

\section{Study population}

Biological fluids were analyzed from a population 41: 17 adults and 24 children less than 12 years old; 28 females, 13 males. The blood samples were taken in the Pasco regional hospital in collaboration with local medical staff on February 13, 2009. People participated in the study of their own volition and gave their informed consent as required by Peruvian law. For underage patients, a parent's signature was obtained. The informed consent was redacted in Spanish and Quechua in order to avoid language discrimination.

\section{Results and discussion}

The three major rivers present in the area were examined for metal and metalloid content in the water and sediments. The Tingo River (T, 3 sample points) flows from the northern part of Cerro de Pasco in the northerly direction until it reaches the Huallaga River ( $\mathrm{H}, 3$ sample points). The Huallaga River flows from the eastern part of Cerro de Pasco to the north before finally reaching the Amazon River. The other major river is the San Juan River (SJ, 4 sample points), which springs in the southern part of Cerro de Pasco and flows in the southern direction until it reaches Junin Lake. In addition to these rivers, tap water in the city (C), waste water of the mine (SM) and water from the Quiulacocha Lake (Q) were analyzed. Quiulacocha Lake has been used as a waste-rock stocking area since mid1970 's. At present, the waste-rock tailings cover $82 \%$ of the surface of the original lake (Wade et al. 2006). Figure 2 shows the sampling points and highlights the flow direction of the rivers. The concentrations of metals and metalloids in the analyzed water samples are reported in Table 5. 
Table 4 Synoptic view of methods' features

\begin{tabular}{lcllllc}
\hline Element & $\begin{array}{l}\text { Maximum } \\
\text { RSD }(\%)^{\mathrm{a}}\end{array}$ & $\begin{array}{l}\text { Minimum } \\
\text { cor fact }(r)\end{array}$ & $\begin{array}{l}\mathrm{m}_{0} \\
(\mu \mathrm{g} / \mathrm{L})\end{array}$ & $\begin{array}{l}\text { CRM reported } \\
(\mu \mathrm{g} / \mathrm{L})\end{array}$ & $\begin{array}{l}\text { CRM experimental } \\
(\mu \mathrm{g} / \mathrm{L})\end{array}$ & $\begin{array}{l}\text { LOD-limit } \\
\text { of linearity }(\mu \mathrm{g} / \mathrm{L})\end{array}$ \\
\hline $\mathrm{Al}$ (serum) & 8 & 0.997 & 0.12 & 41.9 & 42.6 & $0.2-25$ \\
As (blood) & 12 & 0.998 & 15 & 85 & 86.3 & $4-160$ \\
$\mathrm{Cd}$ (blood) & 13 & 0.997 & 0.1 & 5.1 & 5.7 & $0.1-5$ \\
$\mathrm{Cr}$ (serum) & 8 & 0.996 & 0.21 & 0.80 & 0.80 & $0.1-3.5$ \\
$\mathrm{Cu}$ (serum) & 3 & 0.999 & 6 & 1,300 & $5-175$ \\
$\mathrm{Mn}$ (blood) & 4 & 0.996 & 0.1 & 20.9 & 20.5 & $0.02-10$ \\
$\mathrm{Ni}$ (serum) & 14 & 0.996 & 0.6 & 5.1 & 5.1 & $0.5-12$ \\
$\mathrm{~Pb}$ (blood) & 10 & 0.997 & 1 & 22.4 & 21 & $0.2-45$ \\
$\mathrm{Se}$ (serum) & 5 & 0.999 & 2 & 82.4 & 78.5 & $10-175$ \\
\hline
\end{tabular}

$R S D$ relative standard deviation, $C R M$ certified reference material, $L O D$ limit of detection

${ }^{\text {a }}$ Minimum of three readings

Fig. 2 Sampling points of water and sediments. C: Faucet of the city of Cerro de Pasco, SM: Waste water of the mine, H1 Huallaga River 1, H2 Huallaga River 2, H3 Huallaga River 3, $T 1$ Tingo River 1, T2 Tingo River 2, T3 Tingo River 3, SJI San Juan River 1, SJ2 San Juan River 2, SJ3 San Juan River 3, SJ4 San Juan River 4, $Q$ Quiulacocha Lake

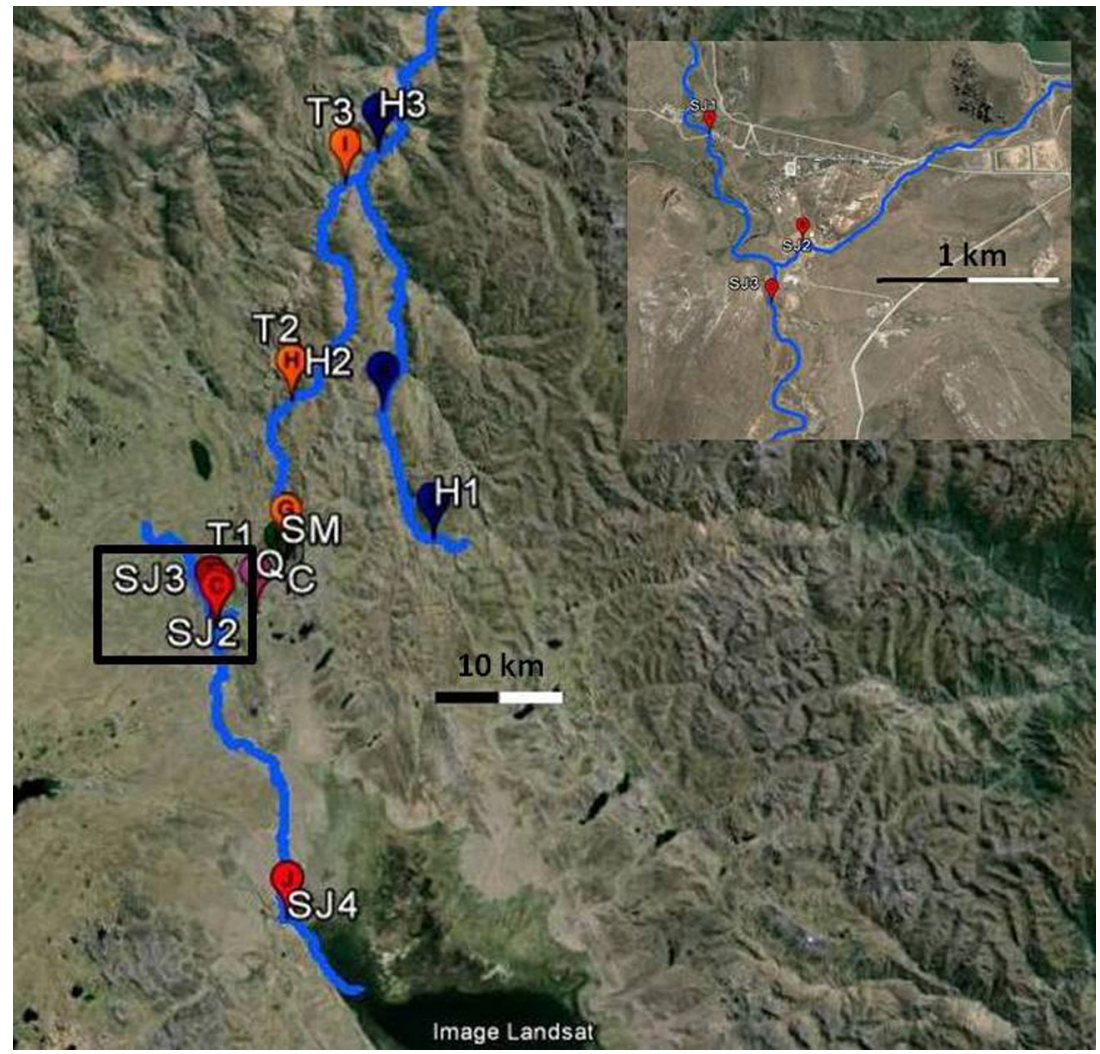

Table 5 shows increased concentrations of various metals and metalloids in the study area, with some elements highly increased, compared with others. In particular, a high concentration of Al was observed in nearly all of the samples, with the highest concentrations for sampling points SJ2, SJ3, SJ4 and Q. Al is the third most abundant element in the earth's crust $(8.1 \mathrm{wt} \%)$. Increased $\mathrm{Al}$ concentrations are often correlated with anthropogenic acidification of natural waters or with physico-chemical characteristics ( $\mathrm{pH}$, presence of ligands, etc.) of the water
(Linthurst et al. 1986). Several investigations have been undertaken to detect natural ligands that can complex $\mathrm{Al}$ in natural waters and to determine the stability constant (Alberti et al. 2005).

Quality standards for Al have been proposed by several international authorities; in particular, a range between 5 and $100 \mu \mathrm{g} / \mathrm{L}$ of soluble $\mathrm{Al}$ is a reference limit for the protection of aquatic life, while a maximum concentration of $200 \mu \mathrm{g} / \mathrm{L}$ is suggested for drinking water (Alberti et al. 2005). 


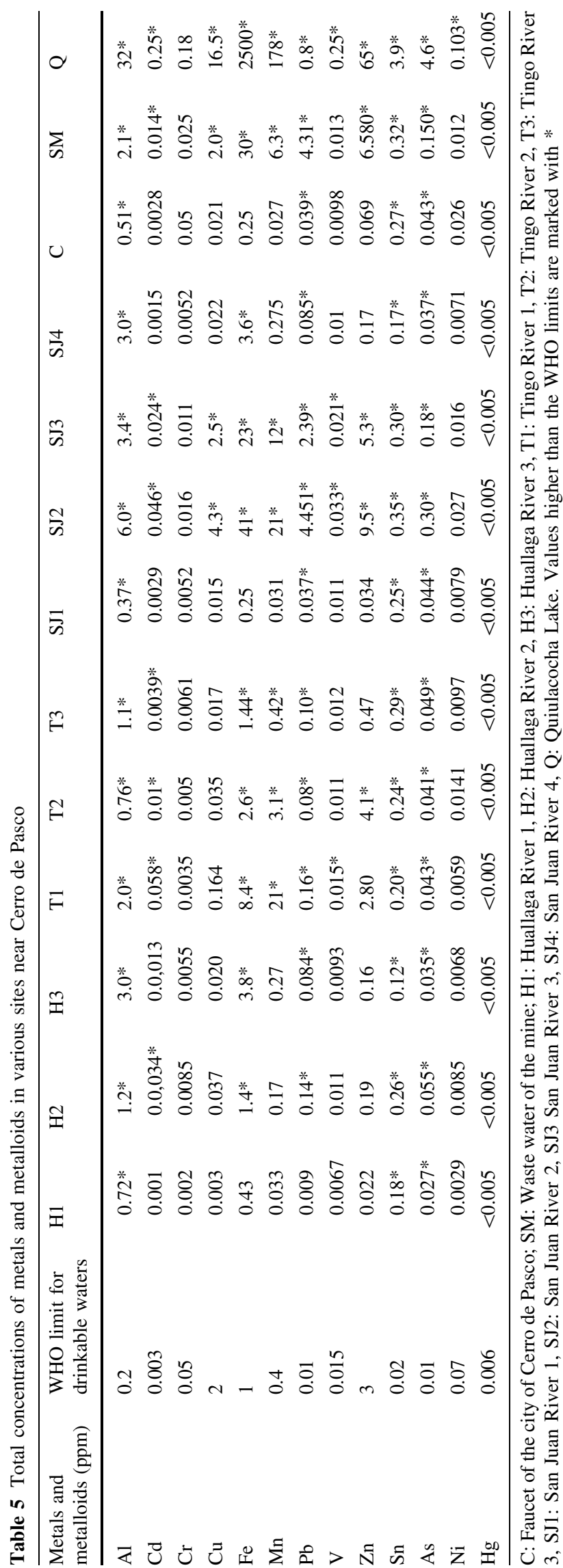

Another element that was very abundant in almost all the samples was $\mathrm{Pb}$, which exceeds the WHO limit in all the samples, with the exception of point $\mathrm{H} 1$, which is upstream of the suspected contamination sources. For $\mathrm{Pb}$, the highest concentrations were reported at sampling points SJ2 and SJ3. Sn also exceeded the WHO limit in all the samples, and its maximum concentration was observed at sampling point Q. The observation is similar for As, particularly for points $\mathrm{SJ} 2, \mathrm{SJ} 3$ and $\mathrm{Q}$. Cr, $\mathrm{Cu}$ and $\mathrm{V}$ exceeded the WHO drinking water limits in only a few points (in the last two cases, the sampling points are $\mathrm{SJ} 2, \mathrm{SJ} 3$ and $\mathrm{Q}$ ), while the $\mathrm{Ni}$ concentrations were high only in samples from point $\mathrm{Q}$. $\mathrm{Hg}$ was not detected in any of the samples collected.

The concentrations of several elements change substantially along the course of the rivers. In the case of the Tingo River, the concentration of all metals and metalloids was higher near the suspected source and is probably related to the presence of a waste deposit located near the spring of this river. In the case of the Huallaga River, the change in the concentration of metals and metalloids is observed between points $\mathrm{H} 1$ and $\mathrm{H} 2$, where the river has a confluence with an artificial minor stream originating from an abandoned tunnel of the underground mine. Finally, in the case of the San Juan River, a substantial increase in the concentrations of all elements was observed between points SJ1 and SJ2. This observation is probably related to the confluence at those points of the San Juan River where a waste duct discharges directly from the open-pit mine. The highly increased metal and metalloid concentrations decrease after point SJ2, probably due to a dilution effect of clean water from other rivers in the area. However, even at sampling point SJ4, approximately $30 \mathrm{~km}$ downstream, the concentration of almost all the measured elements was still higher than in point SJ1.

Table 6 shows the metal and metalloid concentrations (in $\mathrm{mg} / \mathrm{kg}$ ) for sediments collected at the same points as the water sampling. As was observed for the water samples, $\mathrm{Pb}$ is the most abundant element in the sediments. $\mathrm{Zn}$ and $\mathrm{Cu}$ concentrations are relatively higher in the sediment samples than in aqueous samples. It is probable that the presence of sulfides in anoxic waters provokes the formation of non-soluble sulfides that precipitate in the sediments. This may explain why $\mathrm{Ni}$ and $\mathrm{Hg}$ were found to be the lowest in various sites and why $\mathrm{Zn}$ and $\mathrm{Cu}$, which both create very low soluble compounds with sulfides, were higher in sediments than in waters.

Sediments at points SM, SJ2 and SJ3 had the highest metal and metalloid concentrations of those examined. Sampling point $\mathrm{Q}$, which showed the highest concentration in the water samples, did not have comparably high levels in the sediments. This may be related to the observation that the sediments deposited at point $\mathrm{Q}$ have already been processed by the mine. 
Table 6 Concentrations of various metals and metalloids $(\mathrm{mg} / \mathrm{kg})$ in sediments taken from the various points water samples were taken

\begin{tabular}{lrrrrrr}
\hline & \multicolumn{1}{c}{$\mathrm{Pb}$} & $\mathrm{Cr}$ & $\mathrm{Cd}$ & $\mathrm{Cu}$ & $\mathrm{Ni}$ & $\mathrm{Zn}$ \\
\hline $\mathrm{T} 1$ & 852 & 18 & 7 & 481 & 7 & 869 \\
$\mathrm{~T} 2$ & 142 & 14 & 2 & 13 & 6 & 348 \\
$\mathrm{~T} 3$ & 209 & 33 & 59 & 14 & 8 & 413 \\
$\mathrm{H} 1$ & 2 & 27 & 0.8 & 6 & 24 & 10 \\
$\mathrm{H} 2$ & 2,158 & 25 & 3 & 29 & 9 & 298 \\
$\mathrm{H} 3$ & 57 & 12 & 1 & 10 & 13 & 90 \\
SJ1 & 22 & 12 & 2 & 16 & 10 & 53 \\
SJ2 & 3,974 & 12 & 15 & 175 & 19 & 849 \\
SJ3 & 1,109 & 12 & 3 & 166 & 18 & 742 \\
SJ4 & 865 & 16 & 5 & 285 & 17 & 843 \\
SM & 5,980 & 26 & 14 & 286 & 14 & 933 \\
Q & 1,195 & 8 & 51 & 70 & 6 & 403 \\
\hline
\end{tabular}

C: tap of the city of Cerro de Pasco, SM: Waste water of the mine, H1: Huallaga River 1, H2: Huallaga River 2, H3: Huallaga River 3, T1: Tingo River 1, T2: Tingo River 2, T3: Tingo River 3, SJ1: San Juan River 1, SJ2: San Juan River 2, SJ3 San Juan River 3, SJ4: San Juan River 4, Q: Quiulacocha Lake. All concentrations are expressed in $\mathrm{mg} / \mathrm{kg}$

It is difficult to explain the origin and the concentration of various heavy metals in environmental matrices and in particular in the sediments. If metals or metalloids are introduced into natural waters, they generally show a tendency to bind to suspended matter and to accumulate in aquatic sediments through sedimentation. The presence, the concentrations and the fractionation of heavy metals in sediments depend largely on their type of binding forms (Orecchio and Polizzotto 2013; Orecchio and Mannino 2010). Thus, heavy metals adsorbed onto clays and sand can easily be released through ion exchange, in contrast to the much stronger metal-sulfide $(\mathrm{Cu}, \mathrm{Hg}, \mathrm{Sn}$, etc.) bindings and heavy metals incorporated in the sediments. These different metal and metalloid binding forms may show very large variations under the influence of varying environmental conditions. For example, a lowering of sediment $\mathrm{pH}$ may give rise to mobilization of heavy metals bound to carbonates, while sediment and water redox conditions affect the sulfiderelated binding forms of heavy metals.

The presence of metals and metalloids in water and sediments can have strong effect on aquatic life. Several studies have demonstrated that high concentration of heavy metals in water and sediments of rivers can considerably decrease the number of macroinvertebrates, thus affecting entire aquatic life chain (Roline 1988). Furthermore, the presence of metals and metalloids in water can be accumulated in fish as was demonstrated with intentional exposure of sub-lethal concentrations of heavy metals in common carp (Vinodhini and Narayanan 2008).
Several studies (Cristol et al. 2008; Edwards et al. 2009; Velea et al. 2009) show how water pollution can influence the contamination of animal (and probably human) tissues directly and indirectly. We studied this effect by determining the levels of several elements in blood samples. The results obtained are shown in Fig. 3.

The blood samples show increased concentrations in most of the metal and metalloid concentrations determined. In particular, $\mathrm{Cr}$ and $\mathrm{Ni}$ levels were found to dramatically exceed their WHO reference values $(\mathrm{Cr}: 0.1-0.2 \mu \mathrm{g} / \mathrm{L}$; Ni: $0.1-1.0 \mu \mathrm{g} / \mathrm{L})$ for the whole population, with median values of $0.52 \mu \mathrm{g} / \mathrm{L}$ for $\mathrm{Cr}$ and $5.57 \mu \mathrm{g} / \mathrm{L}$ for $\mathrm{Ni}$. In addition, concentrations of $\mathrm{Al}$ and $\mathrm{Mn}$ (reference values $\mathrm{Al}$ : 1.5-6.0 $\mu \mathrm{g} / \mathrm{L} ; \mathrm{Mn}: 3-8 \mu \mathrm{g} / \mathrm{L}$ ) were observed to be higher their reference values for both children and adults (median Al: $20.18 \mu \mathrm{g} / \mathrm{L}$; median Mn: $10.8 \mu \mathrm{g} / \mathrm{L})$.

$\mathrm{Cu}$ was observed in concentrations that are in the lower range of the naturally occurring range $(500-1,250 \mu \mathrm{g} / \mathrm{L})$, with a median value of $683 \mu \mathrm{g} / \mathrm{L}$. It is likely that this observation is related to the osmoregulation mechanisms that control this metal in cells and which tend to counterbalance high exposure levels to other metallic contaminants (Lutsenko 2010).

The concentration of Se was found to be generally higher than the reference values (Se: $20-80 \mu \mathrm{g} / \mathrm{L}$ ) and was markedly higher in adults (median: $140 \mu \mathrm{g} / \mathrm{L}$ ) than in infants (median: $96 \mu \mathrm{g} / \mathrm{L}$ ). Accumulation of this metal is probably due to increasing accumulation over time, since Se is abundant in food (Rayman 2000).

$\mathrm{Pb}$ concentrations were found to be in the high range of the reference values $(1-100 \mu \mathrm{g} / \mathrm{L})$ and was higher in children (median $71.3 \mu \mathrm{g} / \mathrm{L}$ ) compared to adults (median $48.9 \mu \mathrm{g} / \mathrm{L})$. The same phenomenon was observed for As, where the median values for children $(16.39 \mu \mathrm{g} / \mathrm{L})$ were higher than those for adults $(15.81 \mu \mathrm{g} / \mathrm{L})$, and both groups had median values higher than the reference values for this metalloid (1-12 $\mu \mathrm{g} / \mathrm{L})$. However, an inverse phenomenon was noticed for $\mathrm{Cd}$ (reference values: $0.5-1.5 \mu \mathrm{g} / \mathrm{L}$ ) where the median values for children $(0.95 \mu \mathrm{g} / \mathrm{L})$ were lower than those for adults $(1.4 \mu \mathrm{g} / \mathrm{L})$. These differences can be explained by the typical biodistribution and biological halflife of these elements (Luoma and Rainbow 2005). As and $\mathrm{Pb}$ tend to accumulate over time in bones and hair, and this potentially reduces $\mathrm{As}$ and $\mathrm{Pb}$ concentrations in circulating blood. It is likely that children involved in this study had not been exposed to these elements for a long enough period to activate tissue accumulation and thus the children have higher circulating levels, compared to adults. In contrast, $\mathrm{Cd}$ has an entirely different mechanism: this element tends to accumulate in the kidneys and remains in circulation for a long period. This is probably the reason for the higher concentration of $\mathrm{Cd}$ in the blood of adults compared to that of children (Hutton 1987). 
Fig. 3 Distribution of elemental concentrations in blood and serum samples divided between adults and children. The zone highlighted in yellow corresponds to the interval value in healthy patients. All values are in $\mu \mathrm{g} / \mathrm{L}$

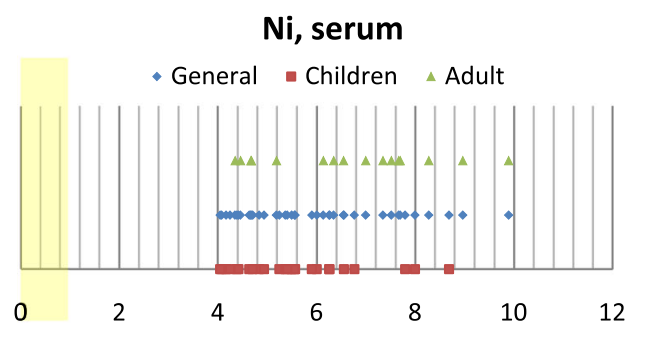

Cr, serum

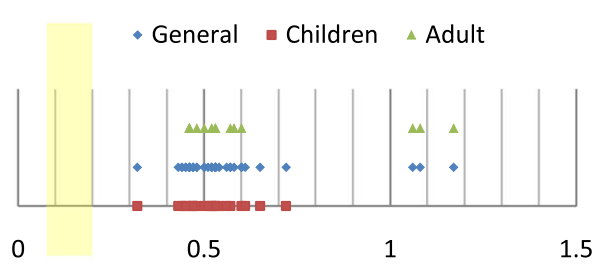

$\mathrm{Pb}$, whole blood

- General - Children $\triangle$ Adult

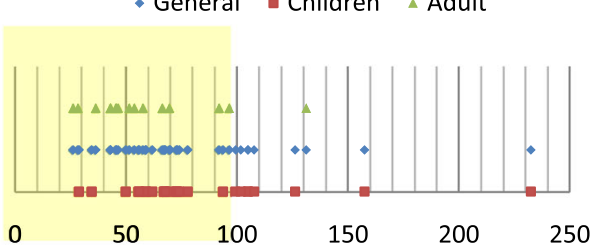

Se, serum

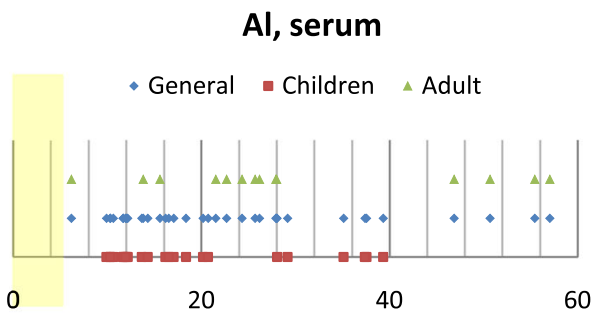

As, whole blood

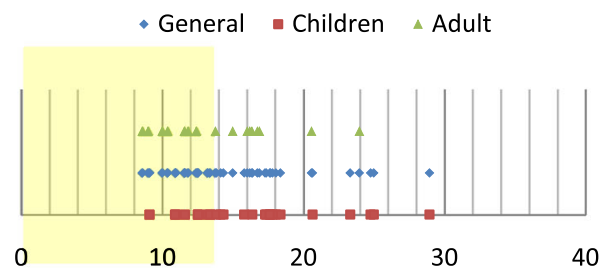

- General - Children $\triangle$ Adult

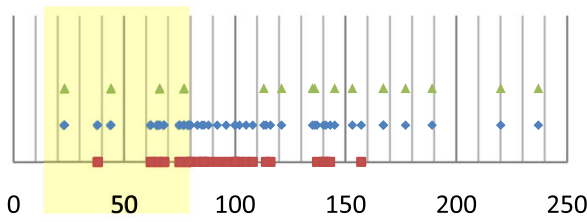

Mn, whole blood

- General - Children A Adult

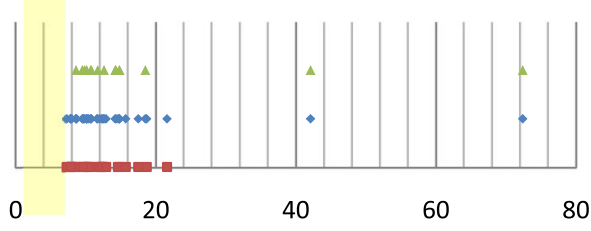

Cu, serum

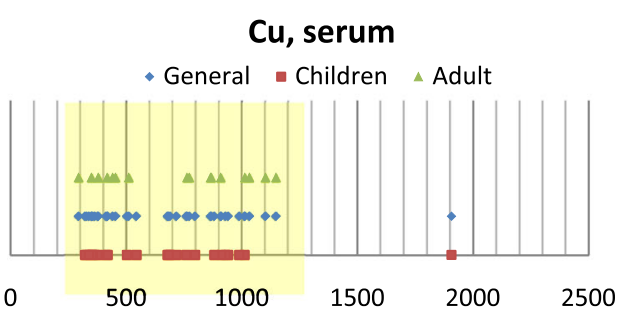

Cd, whole blood

- General - Children $\triangle$ Adult

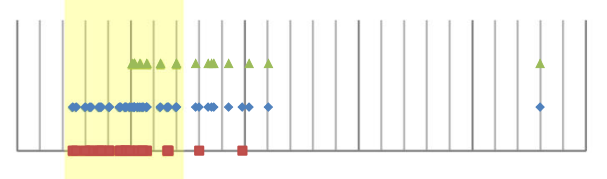

$\begin{array}{lllll}1 & 2 & 3 & 4 & 5\end{array}$

\section{Conclusion}

The city of Cerro de Pasco is located close to a large openpit mine and in recent years, several reports have provided evidence of environmental contamination and related health problems (Conklin et al. 2008; Reporte anual de salud ambiental 2007, 2009). This paper analyzes the elemental contamination in water and sediments of the mining area of Cerro de Pasco and also the internal dose of those elements in human tissues such as blood and serum.
The data collected in this work showed a high concentration of metals and metalloids in the water and in the sediments of the Cerro de Pasco mining area. For some elements, the concentration increased significantly in the samples collected downstream of the mine. This is particularly true for elements such as $\mathrm{Al}, \mathrm{Mn}$ and $\mathrm{Pb}$, and it can be considered a health hazard for the local population.

Biological samples taken from the population of the Paragsha neighborhood (one of the closest neighborhoods to the mine) have shown high concentrations of several 
metals and metalloids. Particularly concerning was the concentration of $\mathrm{Ni}, \mathrm{Al}, \mathrm{Cr}$ and $\mathrm{Mn}$ but also even more dangerous elements such as $\mathrm{As}$ and $\mathrm{Pb}$. The high concentration of those elements in the biological tissues of the local population might be due to the high concentration of these elements in the available drinking water, as well as in the water used to irrigate and feed farm animals, and may represent an increased risk for the health of the area's population.

Acknowledgments Authors are grateful to donors who made this study possible and to the local organization Labor who give all the logistic support in the field work. Moreover, the authors are thankful to Professor Glenn C. Miller for his precious suggestions and to Dr. Lidia Matesic, Dr. Tien Pham and Gillian Blackburn from ANSTO for their useful comments.

\section{References}

Alberti G, D’Agostino G, Palazzo G, Biesuz R, Pesavento M (2005) Aluminium speciation in natural water by sorption on a complexing resin. J Inorg Biochem 99(9):1779-1787. doi:10. 1016/j.jinorgbio.2005.06.017

Ashraf M, Maah M, Yusoff I (2011) Heavy metals accumulation in plants growing in ex tin mining catchment. Int $\mathrm{J}$ Environ Sci Technol 8(2):401-416

Benavides QA (1990) Exploration and mining ventures in Peru. Econ Geol 85(7):1296-1302. doi:10.2113/gsecongeo.85.7.1296

Conklin L, Sánchez CA, Neri A, Staley P, Blumenthal W, Jarrett JM, LePrell R, Durant J, Suarez-Soto RJ (2008) Exposiciones a metales pesados en niños y mujeres en edad fértil en tres comunidades mineras Cerro de Pasco. Centers for Disease Control and Prevention (CDC), Perú

Cooke CA, Abbott MB (2008) A paleolimnological perspective on industrial-era metal pollution in the central Andes Peru. Sci Tot Environ 393(2-3):262-272. doi:10.1016/j.scitotenv.2007.12.034

Cristol DA, Brasso RL, Condon AM, Fovargue RE, Friedman SL, Hallinger KK, Monroe AP, White AE (2008) The movement of aquatic mercury through terrestrial food webs. Science 320(5874):335. doi:10.1126/science. 1154082

Culotta L, Gianguzza A, Orecchio S, Tagarelli A (2008) Sand claims of Ganzirri marine coastal lagoon in Messina (Italy). Extraction and icp-ms analysis. Fresenius Environ Bull 17:131-141

Edwards M, Triantafyllidou S, Best D (2009) Elevated blood lead in young children due to lead-contaminated drinking water: Washington, DC, 2001-2004. Environ Sci Technol 43(5):1618-1623

Einaudi MT (1977) Environment of ore deposition at Cerro de Pasco Peru. Econ Geol 72(6):893-924. doi:10.2113/gsecongeo.72.6. 893

Fisher JR (1977) Silver mines and silver miners in colonial Peru, 1776-1824/by J. R. Fisher. Monograph series (University of Liverpool. Centre for Latin-American Studies); no. 7, vol
Accessed from http://nla.gov.au/nla.cat-vn2493788. Centre for Latin-American Studies, University of Liverpool, (Liverpool)

Hutton M (1987) Human health concerns of lead, mercury, cadmium and arsenic. Lead, Mercury, Cadmium and Arsenic in the Environment. In: TC Hutchinson and KM Meema, (Eds) John Wiley and Sons, Ltd, NY, Toronto

Linthurst R, Landers D, Eilers J, Brakke D, Overton W (1986) Characteristics of lakes in the eastern United States. Volume 1. Population descriptions and physico-chemical relationships. Environmental Protection Agency, Washington, DC (USA). Office of Acid Deposition, Environmental Monitoring, and Quality Assurance

Luoma SN, Rainbow PS (2005) Why is metal bioaccumulation so variable? Biodynamics as a unifying concept. Environ Sci Technol 39(7):1921-1931. doi:10.1021/es048947e

Lutsenko S (2010) Human copper homeostasis: a network of interconnected pathways. Curr Opin Chem Biol 14(2):211-217. doi:10.1016/j.cbpa.2010.01.003

Ngole V, Ekosse G (2012) Copper, nickel and zinc contamination in soils within the precincts of mining and land filling environments. Int J Environ Sci Technol 9(3):485-494

Orecchio S, Mannino MR (2010) Chemical speciation of polycyclic aromatic hydrocarbons in sediments: partitioning and extraction of humic substances. Mar Pollut Bull 60(8):1175-1181

Orecchio S, Polizzotto G (2013) Fractionation of mercury in sediments during draining of Augusta (Italy) coastal area by modified Tessier method. Microchem J 110:452-457

Peterson U (1965) Application of saturation (solubility) diagrams to problems in ore deposits. Econ Geol 60(5):853-893

Purser M (1971) Metal-mining in Peru, past and present. Praeger Publishers, New York

Rayman MP (2000) The importance of selenium to human health. The lancet 356(9225):233-241

Reporte anual de salud ambiental (2007) Direccion Ejecutiva de Salud Ambiental. Lima, Peru

Reporte anual de salud ambiental (2009) Direccion Ejecutiva de Salud Ambiental. Lima, Peru

Roline RA (1988) The effects of heavy metals pollution of the upper Arkansas River on the distribution of aquatic macro invertebrates. Hydrobiologia 160(1):3-8

Tessier A, Campbell PG, Bisson M (1979) Sequential extraction procedure for the speciation of particulate trace metals. Anal Chem 51(7):844-851

Velea T, Gherghe L, Predica V, Krebs R (2009) Heavy metal contamination in the vicinity of an industrial area near Bucharest. Environ Sci Pollut Res 16(1):27-32

Vinodhini R, Narayanan M (2008) Bioaccumulation of heavy metals in organs of fresh water fish Cyprinus carpio (Common carp). Int J Environ Sci Technol 5(2):179-182

Wade C, Dold B, Fontbote L Geochemistry and mineralogy of the quiulacocha tailings impoundment from the polymetallic $\mathrm{Zn}-$ $\mathrm{Pb}-(\mathrm{Ag}-\mathrm{Bi}-\mathrm{Cu})$ deposit Cerro de Pasco, Peru. In: Barnhisel RI (ed) 7th conference on Acid Rock Drainage (ICARD), March 26-30, 2006, St Louis, MO, 2006. American Society on Mining and Reclamation (ASMR), pp 2199-2206

Ward HJ (1961) The pyrite body and copper orebodies, Cerro de Pasco Mine, central Peru. Econ Geol 56(2):402-422 